\title{
SOME NEW AND INTERESTING PORTO RICAN IFAFHOPPERS
}

\author{
By H. L. DOzIER ${ }^{1}$
}

Opportunity is here taken to publish a few interesting records and additions to the leafhoppers of Porto Rico. The writer wishes to

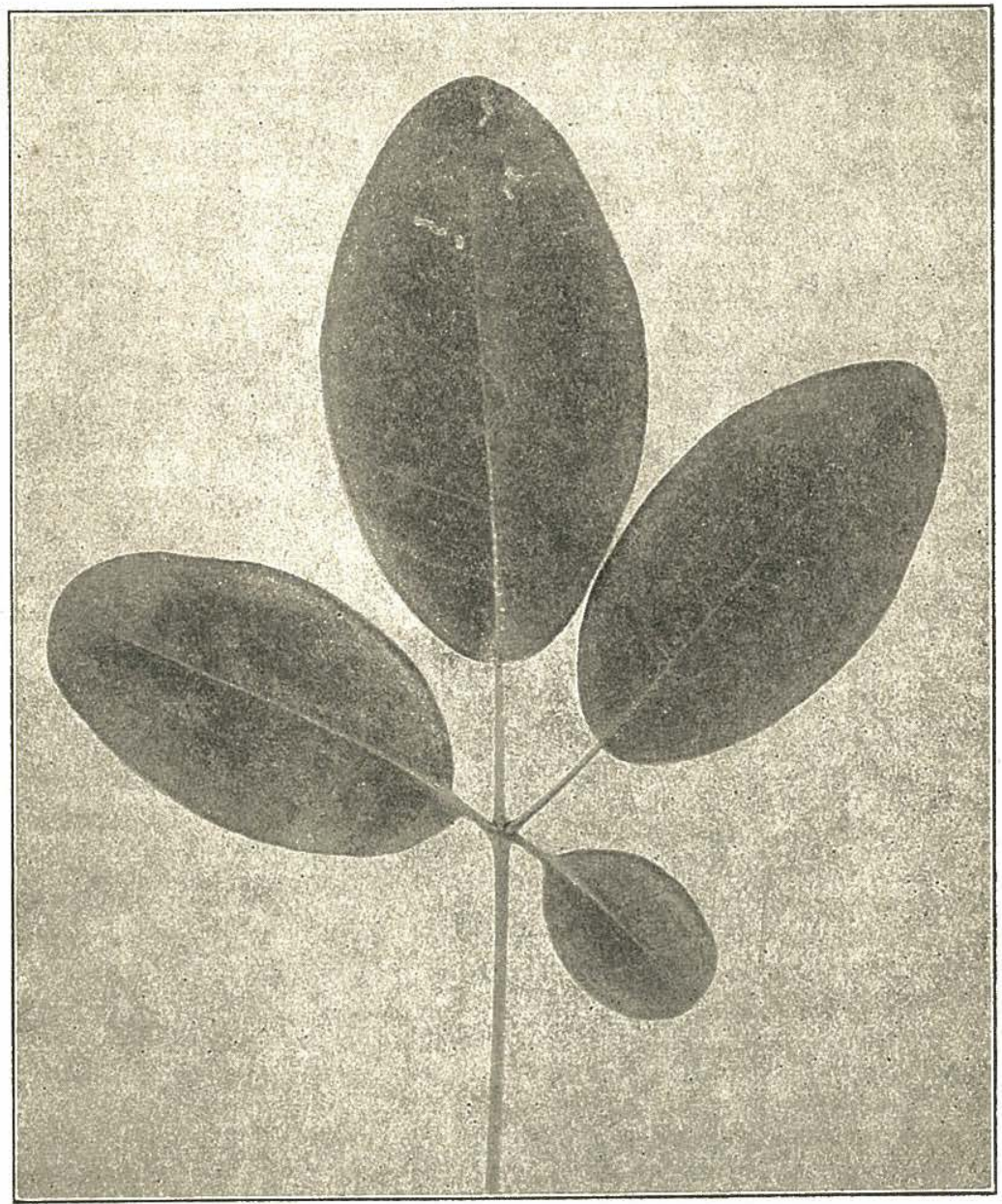

FIG. 1.-Leaves of Roble, Tabebuia pallida, showing the work of Protalebra tabebuia Dozier

thank Mr. W. L. McAtee of the U. S. Biological Survey for determining specifically the Eupterygid species included in this paper.

${ }^{1}$ Formerly Chief Entomologist of the Insular Experiment Station. 


\section{Protalebra tabebuiae, new species}

Head rather broadly rounded although slightly produced. Venátion of wings typical of the genus.

General color of body pale yellowish-white, the vertex and thorax in most specimens with a broad median longitudinal band of orange on dorsum; ground color of the elytra a golden yellow with the inner claval margin, an oblique band across the middle, and another band beginning at the hind margin of the clavus and running across the cross veins, distinctly fuscous; in some specimens there is a Chinese-white irregular patch on the outer costal margin just above the middle fuscous band; the crossveins infuscated, the apical area denoted by them is hyaline. Legs whitish.

Length to tip of elytra, $2.75 \mathrm{~mm}$.

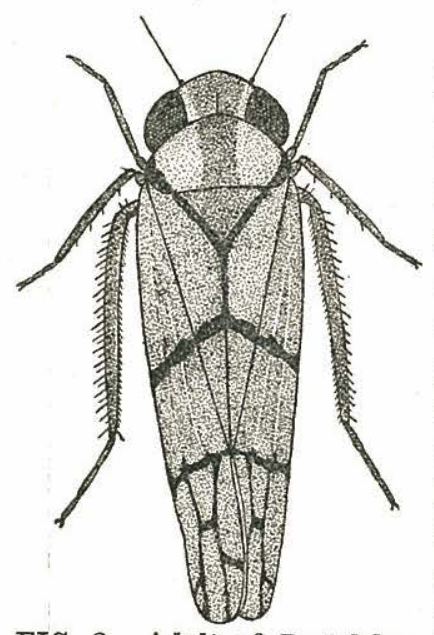

FIG. 2.-Adult of Protalebra tabebuiae Dozier (Original)

Described from numerous specimens of both sexes taken on underside of leaves of "Roble", the West Indian Box Tree, at Río Piedras, Porto Rico, March 10, 1925. It' was found abundant in all stages October 22, 1924, and has been observed to be rather abundant throughout the entire year. "Roble", Tabebuia pallida, is widely used as a shade tree in Porto Rico and its wood is of much economic importance. While this leafhopper often becomes very abundant on it, causing considerable "speckling" of the foliage, the Roble is so hardy that it is able to support large numbers without any apparent injury.

\section{Protalebra similis Baker \\ (1899 Psyche, 8, p. 403)}

A dozen adults were swept by the writer from sweet-potato foliage at Vega Baja, Porto Rico, October 15, 1924. It does not appear to be at all abundant.

\section{Protalebra brasiliensis Baker \\ (1899 Psyche, 8, p. 405)}

This species is the most abundant and generally distributed Protalebra in Porto Rico being commonly met with in cane fields and in weedy places. It is the same species discussed and figured by Wolcott (Jr. of the Dept. of Agri. of Porto Rico, V, p. 31) under the name Erythroneura comes Say. 


\section{Protalebra bifasciata Gillette}

(1898, Proc. U. S. Nat'l. Mus., 20, p. 711)

A single specimen taken by beating a thorny leguminous bush in ravine near Juana Díaz, Porto Rico, February 11, 1925. Recorded from Brazil and Jamaica.

\section{Empoasca minuenda Ball \\ (1922, Proc. Ent. Soc. of Wash., Vol. -)}

The writer found this very small species abundant on undersides of avocado leaves at Río Piedras, Porto Rico, October 22, 1924, and it also attacked the young avocado nursery stock at the Insular Station in large numbers.

\section{Dileraneura (Hyloidea) depressa McAtee}

(1926, Jr. New York Ent. Soc., Vol. XXXIV, p. 162)

This species has been recently described from two females and a male collected by G. N. Wolcott at Vega Alta, Porto Rico, January 21, 1920, and the new subgenus Hyloidea erected for it based on the extraordinary depressed or flattened shape. The original description is given here to make it more available to workers in Porto Rico:

"Female: Head and thorax yellowish in ground color with a percurrent russet to dusky marking covering all but narrow anterior margin of vertex, disk of pronotum, and all but extreme lateral angles of scutellum; apical third of seutellum jet black. Tegmen lemon-yellow, a dusky blotch on middle of clavus, a dusky band over inner crossveins, and a jet black spot on first crossvein; tegminal apex sometimes touched with dusky. Underside stramineous throughout except for the black apex of ovipositor; bristles on ovipositor sheath white. Eighth sternite convex medianly, slightly concave laterally. Male similar to female, marking of head and thorax more or less tinged with reddish laterally; tegmen anterior to fourth crossvein also with a pinkish cast. Venation as in Fig. 15. Length, 2.25-2.75 $\mathrm{mm}$.

"Holotype male, allotype, and another female, Vega Alta, Porto Rico, Janvary 21,1920 , G. N. Wolcott (U. S, N. M.).',

These remarkable leafhoppers are to be found on the undersides of the leaves of maga, Thespesia grandiflora, in limited numbers. The writer found them abundant at Bayamón, Nov. 17, 1924, and made the following color notes. The last instar nymphs are of a general pale whitish color, the elytral pads pale with an orangered longitudinal stripe; the sides of the pronotum and the head except the eyes orange; the eyes pale bluish; scutellum with reddishkrown markings; the second and third abdominal segments a deep reddish-brown. Length $1.75 \mathrm{~mm}$. These nymphs remind one of 
Incle Sam's red, white and blue. Both the adults and nymphs lie closely appressed to the leaf surface, mostly along the mid-ribs, roving when disturbed with a "sideling" or sidewise movement, rarely jumping.

Joruma pisca McAtee

(1924, Fla. Ent., Vol. 8, No. 3-4, p. 34)

The writer took a single specimen at Aguirre, Porto Rico, March

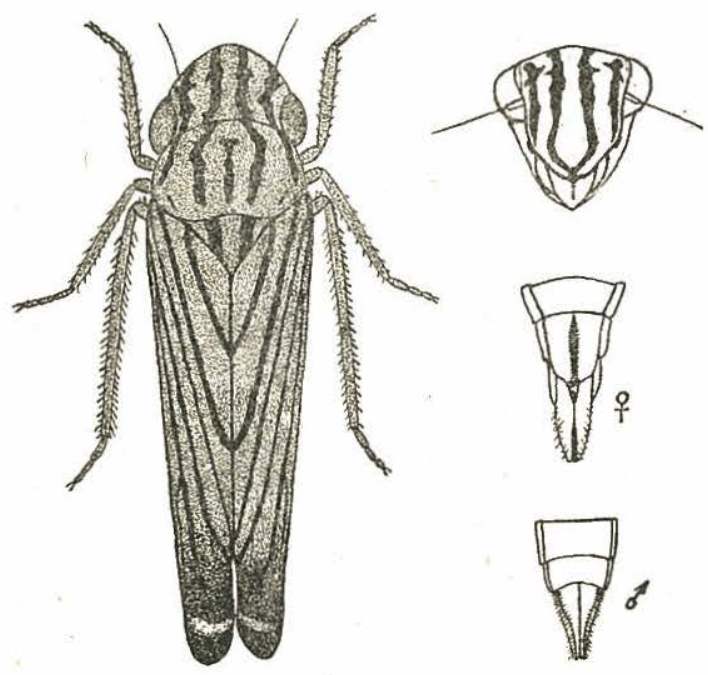

FIG. 3.-Adult female Cicadella coffeaphila Dozier, frons and genitalia (Original) 1, 1925, that has been identified by McAtee as this species.

The two following species have been long confused with each other on acount of their very similar general appearance and habitat and have long been placed under the name Tettigonia occatoria Say (Wolcott, Insectae Portoricensis, p. 259). Upon examination of the large series in the collections of the In-

sular Experiment Station and the American Museum of Natural History, the writer found that they not only are not Say's occatoria but represent two distinct undescribed species. Cicadella occatoria is a somewhat smaller, less robust specie's, and has a single black dot on the pale frons just below the apex of the vertex margin (see Ball, Proc. Iowa Acd. Sci. vin, p. 23, 1901). The writer has not found occatoria either in his personal collecting in Porto Ricg or in the various collections represented. Specimen's, however, are at hand from the American Museum of Natural History collections, taken in June 1911 at Laudet and Long Ditton, Dominica, B.W.I., that must he placed as typical occatoria.

Cicadella coffeaphila and C. coffeacola are both abundant throughout the mountanous coffee-growing regions, particularly the former species, occurring on the coffee and many other host plants among which may be mentioned the jobo and Inga laurina. Both species 
so far are known only from the Island of Porto Rico and appear to be endemic.

\section{Cicadella coffeaphila, new species}

Distinguished at once from Cicadella occatoria by its larger size and different marking on frons.

Vertex as long as basal width, strongly produced beyond the eyes, obtusely sounded, nearly two-thirds as long as the pronotum. Pronotum convex, about as broad at posterior margin as the head. Elytra long and narrow.

General color greenish, the vertex, anterior third of pronotum, and scutellum partially, yellow. Vertex with four irregular more or less longitudinal stripes or vittae that extend over onto the frons where the two median ones converge just before the apex. Pronotum with five more or less broken and irregular black vittae. Scutellum with two rather thick b la ck vittae. The elytra dark green with the vein's heavily marked with black, just before the apex
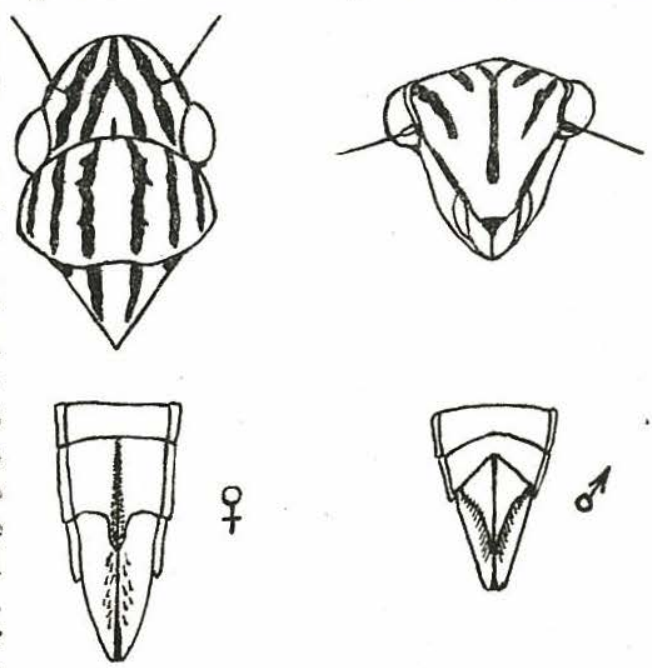

FIG. 4.-Cicadella coffeacola Dozier, showing head, frons, and female and male: genital segments (Original) is a crescent-shaped transverse band of yellow. Body beneath yellowish, the abdomen along middle marked longitudinally more or less with black. Male genital plates distinctly yellow contrasting with the dark pygofers. Legs pale.

Genitalia: female segment over twice as long as the preceding, the median line elevated into a strong keel, the posterior margin strongly angled, the apex formed by the convex keel. Male ultimate segment well-rounded on posterior margin; plates broadened at base, rapidly narrowed to very long acute points that are not or scarcely exceeded by the pygofers.

Length to tip of elytra, 6-6.25 $\mathrm{mm}$.

Described from numerous males and females in the collection of the American Museum of Natural History collected for the most part by Lutz and Mutchler from the following localities in Porto Rico: Cayey, May 30, 1915; Aibonito, June 1-3, 1915; Barros, June 4, 1915; Mayagüez, July 24, 1914, Frank E. Watson; Ja- 
yuya, June 1, 1915, H. E. Crampton; Adjuntas, June 26, 1915 ; and a female collected at Yauco, August 24, 1922, by Sein and Wolcott (Acc. 234-22); and a female collected by the writer on El Yunque, February 17, 1925.

\section{Cicadella coffeacola, new species}

Very similar in general appearance with Cicadella coffeaphila lut easily distinguished by the different markings on vertex, frons and pronotum.

Vertex greatly produced beyond the eyes, obtusely rounded, length and width subequal, two-thirds as long as the pronotum. Pronotum about as broad at posterior margin as the head, convex. Elytra long and narrow.

General color greenish, the vertex yellow with four black stripes or vittae, the two median ones converging to a point at the apex, the outer lateral margins outlined with black. Frons yellow with black median stripe and the lateral ones of the vertex continued over on frons part of its length, the lower sides of frons with black edging; clypeus black. Pronotum greenish, yellow along the anterior third, :six distinct black longitudinal stripes running semi-parallel. Scutellum yellow, with two black median stripes and a black spotting in the upper angles. Elytra deep green, the veins broadly marked in black. Body beneath for the most part yellow, the abdomen marked with broken black along median length. Male plates yellow, the pygofers black. Legs pale.

Genitalia: female segment twice as long as preceding, male ultimate rather deeply incised on hind margin; plates rather broad at base, rapidly narrowing to long acute points, greatly exceeded by the pygofers.

Length to top of elytra, $6-6.25 \mathrm{~mm}$.

Described from a female taken at Río Piedras, Porto Rico, Aug. 1921, G. N. Wolcott (Ace. 266-21) ; a female collected by the writer on coffee, El Yunque, Feb. 17, 1925; and numerous males and females collected by Lutz and Mutchler in American Museum of Natural History collection from Cayey, May 30, 1915; Aibonito, June 1, 1915; and Adjuntas, June 26, 1915.

\section{Macropsis rugicollis, new species}

Easily distiguished by the striking contrast of the bright red head and thorax with the black body and elytra.

Form rather long. Anterior margin of the pronotum molerately and roundingly angulate, produced on the middle distinctly beyond the anterior margin of the eyes, the posterior margin only slightly 
emarginate. Elytra long with the tips broadly rounded, nervures raised.

Color: Entire head a bright red with exception of the very dark reddish-brown eyes. Pronotum bright red with a rather narrow band of black outlining its anterior margin but extending laterally only to about half the width of the eyes above. Remainder of the body, legs and elytra a dark blue-black.

Length, $5.50 \mathrm{~mm}$.

Described from two males taken on the top of mountain at Cerro del Cacique, Santo Domingo, December 17, 1924, by F. Sein at about 5,000 feet elevation, probably from a shrub or tree as members of this genus are so far as known tree-inhabiting forms. 